\title{
The digestion of heather (Calluna vulgaris) by red grouse (Lagopus lagopus scoticus)
}

\author{
By ROBERT MOSS
}

Nature Conservancy, Blackhall, Banchory, Kincardineshire

\author{
AND J. A. PARKINSON
}

Nature Conservancy, Merlewood Research Station, Grange-over-Sands, Lancs.

$$
\text { (Received } 4 \text { December } 1970-\text { Accepted } 3 \text { May 1971) }
$$

I. In the wild, red grouse live largely on heather, a high-fibre $(25 \%)$, low-protein $(7 \%)$ food. Digestibility trials were carried out under semi-natural conditions, with magnesium as a digestibility marker. 'Two trials were done, one in autumn and one in spring.

2. Digestibility of the dry matter varied from $2 \mathrm{I}$ to $30 \%$ and metabolizable energy from $\mathbf{I} \cdot \mathbf{I}$ to $\mathrm{I} .6 \mathrm{kcal} / \mathrm{g}$. These variations were inversely related to intake and could partly be accounted for by facultative variations in holocellulose and lignin digestion.

3. Digestion of soluble carbohydrates, protein (measured as $\alpha$-amino-nitrogen) and holocellulose varied between trials according to the initial concentration in the food. The digestibility of soluble carbohydrate was high $(78-83 \%)$ in autumn $(16 \%$ in food) and low $(6 \mathrm{r}-66 \%)$ in spring ( $\mathrm{I} \%$ in food) and that of protein was relatively low $(24-3 \mathrm{r} \%)$ in autumn $(6 \%$ in food) and high $(42-48 \%)$ in spring ( $7 \%$ in food). Digestibility of crude fat was $30-33 \%$ for four birds and $20 \%$ for one bird.

4. By comparison with poultry, voluntary intake of dry matter was very high relative to bodyweight and intake of energy appeared to be adequate. None the less, all birds lost weight during the trials, presumably for reasons other thin energy shortage.

5. Urate excretion increased in parallel with body-weight losses, but formed only $2 \%$ of the total $\mathrm{N}$ output at low weight losses, in which event the main nitrogenous compounds in the droppings were $\alpha$-amino $N$ (presumably largely from undigested protein), ammonium salts and ornithuric acid.

6. The ornithuric acid was presumably a detoxication product of prolignins and possibly tannins and other polyphenols. Its excretion by grouse corresponds to the excretion of hippuric acid by ruminants.

Heather (Calluna vulgaris [L.] Hull) is the main food of red grouse (Lagopus lagopus scoticus [Lath.]) throughout the year (Jenkins, Watson \& Miller, I963). This paper describes some aspects of its digestion.

Wilson (I II I) has described the intestines of red grouse in detail. Food passes through the oesophagus, crop and proventriculus, and is ground in the muscular gizzard with the aid of small pieces of quartz grit. It then passes into the small intestine, which is about $100 \mathrm{~cm}$ long. At its end there are junctions with the two tubular caecums, each about $75 \mathrm{~cm}$ long. Here the chyme separates into two fractions, a 'pultaceous creamybrown pulp' which is admitted through narrow constrictions into the caecums, and 'hard indigestible waste material' which continues into the short $\left(\mathrm{I}_{2-1} 5 \mathrm{~cm}\right)$, thickwalled large intestine and is excreted in fibrous cylindrical portions; these are described in the present paper as 'woody' droppings. The caecal contents are excreted separately as soft, shapeless, khaki-brown glutinous masses which rapidly turn chocolate brown on the surface. 
EXPERIMENTAL

\section{Birds and their management}

Fully grown cock red grouse from captive stock were kept in cages on a uniform stand of 8-year-old heather. Occasional shoots of Erica cinerea L. and E. tetralix L. and small patches of grass and moss which were interspersed with the heather did not appear to be eaten. The cages, which covered an area $2 \cdot \mathrm{I} \times \mathrm{I}^{\cdot} 5 \mathrm{~m}$, were moved to fresh heather each morning, when the birds were also weighed. Water and granite grit were always available.

Table $\mathrm{I}$. Gross energy and inorganic components of dried heather and dried red grouse droppings

\begin{tabular}{|c|c|c|c|c|c|c|c|c|c|}
\hline & Bird & $\begin{array}{c}\text { Gross } \\
\text { energy } \\
(\mathrm{kcal} / \mathrm{g})\end{array}$ & $\% \mathrm{~N}$ & $\% \mathbf{P}$ & $\% \mathrm{Ca}$ & $\% \mathrm{Mg}$ & $\% \mathrm{~K}$ & $\% \mathrm{Na}$ & $\%$ ash \\
\hline \multirow[t]{5}{*}{ Crop contents } & $A_{\mathbf{I}}$ & $5 \cdot 27$ & $\mathbf{I} \cdot 07 \%$ & 0.063 & 0.53 & 0.164 & 0.42 & 0.10 & $4 \cdot 66$ \\
\hline & $\mathrm{A}_{4}$ & $5 \cdot 32$ & $0.98 *$ & 0.071 & 0.45 & 0.140 & 0.42 & 0.15 & 4.21 \\
\hline & A 6 & 5.40 & $0.99^{*}$ & 0.073 & 0.45 & 0.173 & 0.37 & 0.14 & $4 \cdot 15$ \\
\hline & $\mathrm{S}_{2}$ & $5 \cdot 30$ & $I \cdot 13 *$ & 0.083 & 0.62 & 0.193 & 0.53 & 0.19 & $4 \cdot 93$ \\
\hline & $\$ 6$ & $5^{1} 19$ & $I \cdot I 5 *$ & 0.093 & 0.54 & 0.178 & $0.6 \mathrm{I}$ & 0.18 & $4 \cdot 63$ \\
\hline \multirow[t]{5}{*}{ Picked samples } & $A_{1}$ & $5 \cdot 33$ & 0.97 & 0.066 & 0.38 & 0.156 & $0 \cdot 37$ & 0.05 & $3 \cdot 40$ \\
\hline & $\mathrm{A}_{4}$ & $5 \cdot 36$ & 0.94 & 0.067 & 0.45 & 0.140 & $0 \cdot 37$ & 0.05 & $3 \cdot 66$ \\
\hline & A 6 & 5.41 & 1.02 & 0.074 & 0.45 & $0.15^{6}$ & 0.37 & 0.05 & $3 \cdot 47$ \\
\hline & $\mathrm{S} 2$ & $5 \cdot 21$ & $I \cdot I T$ & 0.076 & 0.53 & 0.169 & 0.49 & 0.06 & $4 \cdot 81$ \\
\hline & S6 & $5 \cdot 21$ & $I \cdot 10$ & 0.082 & $0.5 \mathrm{I}$ & $0 . \times 59$ & 0.58 & 0.06 & $4 \cdot 43$ \\
\hline \multirow[t]{5}{*}{ Woody droppings } & $A_{\mathbf{I}}$ & 5.40 & $2 \cdot 16$ & 0.106 & 0.68 & 0.218 & 0.04 & 0.03 & $5 \cdot 92$ \\
\hline & $\mathrm{A}_{4}$ & $5 \cdot 48$ & $I \cdot 24$ & 0.031 & 0.71 & 0.173 & 0.03 & 0.04 & $4 \cdot 83$ \\
\hline & A6 & $5 \cdot 44$ & $\mathrm{I} \cdot 07$ & 0.032 & $0^{\circ} 5^{6}$ & 0.180 & 0.12 & 0.05 & $5 \cdot 37$ \\
\hline & $\mathrm{S}_{2}$ & $5 \cdot 35$ & $\mathrm{r} \cdot 49$ & 0.086 & 0.77 & 0.206 & 0.13 & 0.07 & $7 \cdot 15$ \\
\hline & 56 & $5 \cdot 39$ & $I \cdot 59$ & 0.084 & 0.71 & 0.197 & 0.16 & 0.05 & $7 \cdot 31$ \\
\hline \multirow[t]{5}{*}{ Caecal droppings } & A r & $4 \cdot 96$ & $3 \cdot 66$ & 0.62 & 0.15 & 0.140 & $4 \cdot 50$ & 0.21 & I $2 \cdot 6$ \\
\hline & $\mathrm{A}_{4}$ & $4 \cdot 90$ & $3 \cdot 30$ & 0.68 & 0.15 & 0.280 & 4.15 & 0.23 & $x 2 \cdot 6$ \\
\hline & A 6 & 4.94 & $3 \cdot 8 \mathrm{I}$ & 0.90 & 0.18 & 0.260 & 435 & 0.52 & $\mathrm{I}_{3} \cdot 2$ \\
\hline & $\mathrm{S}_{2}$ & 479 & 3.59 & 0.93 & 0.24 & 0.319 & 4.63 & 0.24 & I 5.0 \\
\hline & S6 & $4 \cdot 78$ & $3 \cdot 19$ & 0.79 & 0.19 & 0.253 & $4 \cdot 3^{8}$ & 0.27 & $\mathrm{I} 6 \cdot 2$ \\
\hline
\end{tabular}

* Corrected for contamination by saliva, which was calculated from the known ratio of sodium to nitrogen $(1: 0.50 ;$ Moss, 1967$)$ in grouse saliva by assuming that all the difference in sodium between crop contents and picked samples was due to saliva.

The birds had been accustomed to a dict of artificial pellets (I $8 \%$ protein, i $\%$ fibre), together with a small amount of heather, and took some time to adapt to an all-heather diet (about $7 \%$ protein, $25 \%$ fibre). For the rst week of each experiment the birds were given pellets $a d$ lib., and then the amount of artificial food was reduced over a period of $\mathrm{s} 0$ or more days. Some birds adapted to the heather quite well and lost weight only slowly. Others lost weight rapidly and most of these were removed from the experiment. 'The 'woody' (i.e. non-caecal) droppings of the better-adapted birds gradually increased in length and diameter and the initially conspicuous white urate caps derived from the dehydrated urine decreased until little or no trace remained. In both these rcspects they now resembled droppings of wild birds, rather than of captive birds. Urates remained conspicuous in droppings of birds which failed 
to adapt, although in some the droppings increased in size. Birds from captive stock invariably have much shorter intestines and caecums and smaller gizzards than wild birds (Moss, 1972).

After 5-7 d on heather alone, all the droppings of each bird were collected daily for $5-7 \mathrm{~d}$. The two types of droppings were collected separately. Occasionally this was not possible because the droppings were inextricably mixed, in these few instances the mixed material was added to the woody droppings. A knife was useful for removing the slimy caecal droppings from the heather.

Table 2. Organic components $(\%)$ of dried heather and dried red grouse droppings

\begin{tabular}{|c|c|c|c|c|c|c|c|}
\hline & Bird & Lignin & $\begin{array}{l}\text { Holo- } \\
\text { cellulose }\end{array}$ & $\begin{array}{c}\alpha-C \text { ellu- } \\
\text { lose }\end{array}$ & $\begin{array}{l}\text { Soluble } \\
\text { carbo- } \\
\text { hydrate }\end{array}$ & $\begin{array}{l}\text { Ether } \\
\text { extract }\end{array}$ & $\begin{array}{l}\text { Soluble } \\
\text { tannin }\end{array}$ \\
\hline \multirow[t]{5}{*}{ Crop contents } & $A_{I}$ & 18 & 35 & 14 & I9 & $8 \cdot 7$ & $10 \cdot 8$ \\
\hline & $A_{4}$ & $2 \mathrm{I}$ & 35 & I 3 & 17 & $9 \cdot 4$ & $10 \cdot 8$ \\
\hline & A 6 & 23 & 40 & 14 & 14 & $9 \cdot 0$ & $I I \cdot I$ \\
\hline & $S_{2}$ & 19 & 43 & 17 & I3 & - & - \\
\hline & S6 & 20 & 42 & I6 & 12 & $9^{-8}$ & $10 \cdot 8$ \\
\hline \multirow[t]{5}{*}{ Picked samples } & $A_{I}$ & 22 & 38 & 13 & 16 & $8 \cdot 8$ & $10 \cdot 2$ \\
\hline & $\mathrm{A}_{4}$ & 20 & 37 & I3 & I8 & $8 \cdot I$ & I0.8 \\
\hline & A 6 & 25 & $3^{8}$ & 14 & 14 & $8 \cdot 0$ & $7 \cdot 0$ \\
\hline & $\mathrm{S}_{2}$ & 23 & 42 & 17 & I6 & $8 \cdot 5$ & 10.3 \\
\hline & S6 & 23 & 42 & 14 & $1_{4}$ & $8 \cdot 6$ & $9 \cdot 6$ \\
\hline \multirow[t]{5}{*}{ Woody droppings } & $A_{\text {I }}$ & 26 & 49 & 17 & 4 & 977 & $8 \cdot 4$ \\
\hline & $\mathrm{A}_{4}$ & 27 & $5^{2}$ & 20 & 4 & $9 \cdot 8$ & $8 \cdot 2$ \\
\hline & A 6 & 27 & 52 & 211 & 5 & $8 \cdot 8$ & $6 \cdot I$ \\
\hline & $S_{2}$ & 28 & 54 & 22 & 5 & 10.5 & $8 \cdot 9$ \\
\hline & S6 & 26 & $5 \mathrm{I}$ & 23 & 6 & $12 \cdot 0$ & $9^{-1}$ \\
\hline \multirow[t]{5}{*}{ Caecal droppings } & $A_{I}$ & 8 & $<2$ & $<2$ & I4 & $I \cdot 2$ & $19 \cdot 4$ \\
\hline & $\mathrm{A}_{4}$ & I3 & $<2$ & $<2$ & I 5 & $I \cdot 6$ & 20.9 \\
\hline & A 6 & 25 & $<2$ & $<2$ & 14 & $I \cdot I$ & I9:7 \\
\hline & $\mathrm{S}_{2}$ & Jo & $<2$ & $<2$ & $x_{4}$ & $I \cdot 6$ & $22 \cdot 3$ \\
\hline & S 6 & IO & $<2$ & $<2$ & I 2 & $\mathrm{I}-8$ & $25 \cdot 4$ \\
\hline
\end{tabular}

The heather eaten was sampled in two ways: $(a)$ each day a sample of heather was taken adjacent to each cage and the current year's growth (Moss, r969) was separated from it for analysis; $(b)$ the birds were killed at the end of each trial after dusk, when their crops were full, and the crop contents were taken. Samples were stored at $-5^{\circ}$, then freeze-dried and milled to pass through a $0.7 \mathrm{~mm}$ mesh sieve. The daily samples were analysed separately for magnesium, and further determinations (Tables I and 2) were made upon crop contents and the last daily samples.

Trials were done at two different seasons, in autumn 1967 after the heather had finished growing, and in spring 1968 when it had just started to grow. Three birds (A I, $\mathrm{A}_{4}$ and $\mathrm{A6}$ ) were used for the autumn trials, two ( $\mathrm{S}_{2}$ and $\mathrm{S} 6$ ) for the spring.

\section{Calculation of digestibilities}

Magnesium was used as a marker to calculate apparent digestibilities (A, \%) from the formula

$$
A=\left(\mathrm{r}-\frac{X_{\mathrm{D}} \times \mathrm{M}_{\mathrm{F}}}{X_{\mathrm{F}} \times \mathrm{M}_{\mathrm{D}}}\right)_{\text {гоo, }}
$$


where $X_{\mathrm{D}}=X_{\mathrm{W}} \times \mathrm{DM}_{\mathrm{W}}+X_{\mathrm{C}} \times \mathrm{DM}_{\mathrm{C}}, \mathrm{M}_{\mathrm{D}}=\mathrm{M}_{\mathrm{W}} \times \mathrm{DM}_{\mathrm{W}}+\mathrm{M}_{\mathrm{C}} \times \mathrm{DM}_{\mathrm{C}}, X_{\mathrm{F}}$ or $\mathrm{M}_{\mathrm{F}}=$ $\%$ of constituent $X$ or $\mathrm{Mg}$ in food, $X_{\mathrm{W}}$ or $\mathrm{M}_{\mathrm{W}}=\%$ of constituent $X$ or $\mathrm{Mg}$ in the dried woody droppings, $X_{\mathrm{C}}$ or $M_{\mathrm{C}}=\%$ of constituent $X$ or $\mathrm{Mg}$ in the dried caccal droppings, $\mathrm{DM}_{\mathrm{W}}=\%$ of dry droppings formed by woody droppings, $\mathrm{DM}_{\mathrm{C}}=\%$ of dry droppings formed by caecal droppings. The value of $M_{D}$ that was used incorporated the correction for weight loss of which details are given in the section Sources of error.

Table 3. Percentage of lignin in food (heather) and droppings of red grouse in early tests (from Moss, 1967) (dry basis)

$\begin{array}{cccc}\text { Licked } & \begin{array}{c}\text { Crop } \\ \text { heather }\end{array} & \begin{array}{c}\text { Combined } \\ \text { contents }\end{array} & \begin{array}{c}\text { droppings } \\ \text { Late winter, I965 }\end{array} \\ & 26 & 23 & 26 \\ & 26 & 24 & 26 \\ & 27 & & 25 \\ & 26 & & 25 \\ \text { Early spring, } 1965 & 26 & & 25 \\ & 26 & 22 & 26 \\ & 24 & 25 & 25 \\ & 27 & & 22 \\ & & & 22\end{array}$

Table 4. Apparent digestibility of dry matter of an artificial diet measured directly and using $M g$ as a marker

$\begin{array}{lccc}\text { Bird ... } & \text { I } & 2 & 3 \\ \text { Food eaten (g) } & 196 & 26 \mathrm{I} & 204 \\ \text { Droppings (g) } & 120 & 156 & 128 \\ \text { Apparent digestibility (\%) } & 39 & 40 & 37 \\ \text { Mg in food (\%) } & 0.19 & 0.19 & 0.19 \\ \text { Mg in droppings (\%) } & 0.31 & 0.34 & 0.31 \\ \begin{array}{c}\text { Correction for bird's } \\ \text { weight loss }(\% \mathrm{Mg})\end{array} & 0 & 0.01 & 0 \\ \begin{array}{c}\text { Estimated apparent } \\ \text { digestibility (\%) }\end{array} & 39 & 42 & 39\end{array}$

The trial lasted for $5 \mathrm{~d}$.

Initially, the use of lignin had been considered as a marker (Moss, 1967). However, early results showed that the lignin content of the combined woody and caecal droppings could in some instances be almost as low as that of the food (Table 3). If lignin had been used as a marker, apparent digestibility would have approached zero in these instances, which is absurd. Clearly, lignin was being digested and was not an appropriate markcr.

In principle, it should be possible to use any mineral element as a marker for digestibility studies in birds, as long as they are in balance for that element. This is because they excrete their solid urine along with the faeces, unlike mammals which lose a proportion of each element in their liquid urine.

$\mathrm{Mg}$ was examined for use as a marker because it is poorly absorbed by herbivores. For example, its availability to mature sheep and cattle feeding on vegetation seldom exceeds $30 \%$ (Rook \& Storry, I962). Thus any slight deviations from elementary balance should be less important for $\mathrm{Mg}$ than for other, more available elements. To 
maximize the probability of the assumed Mg balance, all birds were used when they were neither moulting, laying nor growing.

A laboratory test using a diet based on dried-grass meal $(56 \%)$, ground oats $(25 \%)$ and extracted soya-bean meal (12\%), together with minerals and vitamins, showed reasonable agreement between apparent digestibility measured directly from drymatter intake and output and that estimated using $\mathrm{Mg}$ as a marker (Table 4). It therefore seemed that $\mathrm{Mg}$ would be an appropriate marker for use in the present trials.

In estimating the chemical composition of the heather eaten in the present trials, for constituents other than $\mathrm{Mg}$ the values for the two or three birds in each trial were combined.

Sometimes there were differences between the samples of heather from the crops of the birds and the samples taken adjacent to the cages on the final day. Less lignin and ether extractives were found in the crop contents than in the picked samples in both the autumn and spring trials, and less soluble carbohydrates in the spring trial only (Table 2). In addition, there was more total $\mathrm{N}$ in the crop contents, even after correction for $\mathrm{N}$ in the saliva (Table $\mathrm{I}$ ). These differences confirmed earlier comparisons (Moss, 1967 ).

Where constituents did not obviously differ between crop contents and picked samples, the mean value for the results of the analyses of both types of sample was used to calculate digestibilities. When they did differ, the mean of the crop contents only was used.

\section{Sources of error}

A comparison between the $\mathrm{Mg}$ content of heather from eleven pairs of crops and the adjacent picked samples showed that most of the variation in the picked samples was reflected in the crop contents $(r=0.824, P<0.01)$. The residual variation not accounted for by this correlation might well have introduced error when the mean of the picked samples was used to estimate the mean of the crop samples: the mean of the crop samples in this comparison was $0.147 \% \mathrm{Mg}$, with a sample standard error of $0.0055 \%$ due to deviations from the regression of the crop contents on the picked samples. Such a level of variability would have caused an error of about 3 percentage units in the calculation of dry-matter digestibilty for the different birds if the estimated mean $\mathrm{Mg}$ content of the diet was in error by one sample standard error. This is the order of the possible inaccuracy due to estimating $\mathrm{Mg}$ intake.

The birds lost weight during the trials and were therefore likely to be excreting more $\mathrm{Mg}$ than they ate. Correction was made for this by assuming that the measured weight loss was due to catabolism of muscle and that the $\mathrm{Mg}$ content of fresh grouse muscle was $0.0336 \%$, the value for poultry given by Wacker \& Vallee (1964). Assuming that all the $\mathrm{Mg}$ in the catabolized muscle was excreted, the biggest correction - for bird A r which lost $12 \mathrm{~g} / \mathrm{d}$ - amounted to an estimated change in dry-matter digestibility from $33 \%$ to $30 \%$. Corrections for the other birds (weight losses, I, 2, 3 and $6 \mathrm{~g} / \mathrm{d})$ were correspondingly smaller.

Additional errors in calculating the digestibility of proximate constituents may have occurred if the samples analysed were not representative of what the birds had been eating through the trial. There were not enough results to analyse this possibility. 
It was easy to find and collect all the hard, fibrous woody droppings. However, a small proportion of the caccal droppings sometimes remained adhering to the heather. To estimate this error, caecal droppings were weighed, dropped on to heather, collected and reweighed. Recovery was always greater than $95 \%$. A loss of $5 \%$ of the caecal droppings would have changed calculated digestibilities by less than $0.5 \%$. Estimates of dietary intakes would have been reduced by about $0.5 \%$. These effects are negligible in relation to other errors.

\section{Inorganic constituents}

\section{Chemical analysis}

Total $\mathrm{N}$ was determined by a semi-micro-Kjeldahl digestion with $\mathrm{HgO}$ as catalyst, followed by colorimetric estimation of the $\mathrm{NH}_{3}$ formed by the indophenol blue reaction using a Technicon AutoAnalyzer (Technicon Instruments Co. Ltd, Chertsey, Surrey). Other inorganic ions were determined after digestion with $\mathrm{H}_{2} \mathrm{SO}_{4}-\mathrm{HNO}_{3}$ $\mathrm{HClO}_{4}$ mixture: sodium and potassium by flame-emission spectrophotometry, calcium and $\mathrm{Mg}$ by atomic absorption spectrophotometry and phosphorus colorimetrically by a molybdenum blue method.

\section{Organic fractions}

Ether extract was determined by extraction with diethyl ether for $4 \mathrm{~h}$ (Association of Official Agricultural Chemists, I965).

Soluble carbohydrate was determined on a hot-water extract by the anthrone colorimetric method based on that of Deriaz (I96r), using glucose as the standard.

Soluble tannin was determined on a hot-water extract by a Folin-Denis colorimetric procedure (Association of Official Agricultural Chemists, 1965), using tannic acid as the standard.

Holocellulose was determined gravimetrically by the method of Wise, Murphy \& D'Addieco (1946).

$\alpha$-Cellulose was estimated after treatment of the holocellulose residue following the method of Bath (1960).

Lignin was determined by the method of Ritter, Seborg \& Mitchell (1932), modified by replacing the initial extractions with ethanol and ethanol-benzene by a single extraction with diethyl ether for $4 \mathrm{~h}$.

\section{Nitrogen fractionation}

Free $\mathrm{NH}_{4}{ }^{+}-N$. This was determined by a direct distillation method. A I $g$ portion of freeze-dried material was placed in an ammonia distillation apparatus similar to that described by Hoskins (1944); $15 \mathrm{ml}$ water and $0.08 \mathrm{~g} \mathrm{MgO}$ were added and the $\mathrm{NH}_{3}$ distillate was collected in $5 \mathrm{ml} \mathrm{H}_{3} \mathrm{BO}_{3}$-mixed indicator (Sher, I955) and titrated with $0.007 \mathrm{M}-\mathrm{HCl}\left(\mathrm{I} \mathrm{ml} \equiv 0.1 \mathrm{mg} \mathrm{NH}{ }_{4}{ }^{-} \mathrm{N}\right)$.

$\mathrm{NH}_{4}{ }^{+}+$amide $\mathrm{N}$. A I g portion of freeze-dried material ( $0.3 \mathrm{~g}$ for caecal droppings) was hydrolysed by refluxing for $16 \mathrm{~h}$ with $20 \mathrm{ml} 6 \mathrm{M}-\mathrm{HCl}$. The hydrolysate was filtered, then rapidly neutralized to $\mathrm{pH} 6.5$ with $\mathrm{NaOH}$ solution and diluted to $200 \mathrm{ml}$. The solution was stored in the deep-freeze at $-15^{\circ}$ until required for analysis. A Io $\mathrm{ml}$ 
portion of the hydrolysate was transferred to the distillation apparatus and $0.08 \mathrm{~g}$ $\mathrm{MgO}$ was added. The $\mathrm{NH}_{3}$ was distilled and titrated as above.

$\alpha$-Amino N. A $5 \mathrm{ml}$ portion of the hydrolysate prepared for determination of $\mathrm{NH}_{4}{ }^{+}+$ amide $\mathrm{N}$ was used in the methods described for $\alpha$-amino acid $\mathrm{N}$ by Bremner (1965), except that the mixed indicator of Sher (1955) was used and $0.007 \mathrm{M}-\mathrm{HCl}$ was used for the titration.

Creatine +creatinine N. A $0.2 \mathrm{~g}$ portion of freeze-dried material was boiled gently for $2 \mathrm{~h}$ with $30 \mathrm{ml} \mathrm{O} \cdot \mathrm{I} \mathrm{M}-\mathrm{HCl}$. The flask was topped-up to $30 \mathrm{ml}$ at intervals with O.I $\mathrm{M}-\mathrm{HCl}$ to replace losses due to evaporation. The extract was filtered hot, the filter-paper was washed with hot water and, after cooling, the solution was diluted to I00 $\mathrm{ml}$. A ro $\mathrm{ml}$ portion of the extract was shaken vigorously for $5 \mathrm{~min}$ with $0.5 \mathrm{~g}$ polyvinylpyrrolidone (PVP), to remove polyphenols which were found to interfere with the colorimetric procedure. A $5 \mathrm{ml}$ sample of the PVP-treated extract was used in the colorimetric procedure of Owen, Iggo, Scandrett \& Stewart (1954). Creatinine was used as the standard.

Uric acid $N$. This was determined by the method of Tinsley \& Nowakowski (1957), modified to include the polyphenol removal stage using PVP as described for creatine + creatinine $\mathrm{N}$ above. The final measurement was made with a u.v. spectrophotometer at $282 \mathrm{~nm}$ in preference to the titration used by Tinsley \& Nowakowski (I957).

Ornithuric acid $N$. Thin-layer chromatography on micro-crystalline cellulose was used to separate ornithuric acid after extraction of woody droppings with industrial methylated spirit and preliminary purification on a cellulose column. The spots were identified with $p$-dimethylaminocinnamaldehyde (Baldwin, Robinson \& Williams, r960). Full details of this technique are to be published separately.

\section{Other analyses}

Gross energy values were determined in an adiabatic bomb calorimeter. Volatile fatty acids (VFA) were measured by the method of Faichney (1969).

\section{RESULTS}

\section{Chemical composition of food and droppings}

The caecal droppings formed only I0- $3 \%$ of the total excrement on a dry-weight basis (Table 6) and their chemical composition was very different from that of the woody droppings (Tables $I$ and 2). The caecal droppings were much richer in $\mathrm{N}, \mathrm{P}, \mathrm{K}$ and $\mathrm{Na}$ than the woody droppings, contained similar amounts of $\mathrm{Mg}$, and much less $\mathrm{Ca}$. As a result, most of the $\mathrm{K}$, approximately half the $\mathrm{P}$ and $\mathrm{Na}$, and about a quarter of the $\mathrm{N}$ excreted by the birds were contained in the caecal droppings (Table 5). Most of the $\mathrm{Ca}$ and $\mathrm{Mg}$ were excreted in the woody droppings. The amounts of some organic constituents also differed markedly between the two types of dropings. The crude fat content of the woody droppings was similar to that in the food, at about $10 \%$. By contrast, the caecal droppings contained only about $1 \cdot 5 \%$ crude fat. Soluble carbohydrates were reduced to about $5 \%$ in the woody droppings, compared with about $15 \%$ in the food and in the caecal droppings. The food contained about 
10\% soluble tannins. Concentrations in the woody droppings were slightly lower than this, but the concentration was doubled to about $20 \%$ in the caecal droppings.

Holo- and $\alpha$-cellulose were not detected in the caecal droppings, but the woody droppings contained more than the food. There was more lignin in the woody dropings than in the food, and a lesser but very variable amount in the caecal droppings. The concentration of lignin in the dried caecal droppings was inversely correlated with the extent of lignin digestion (Tables 2 and $3 ; r=-0.8 \mathrm{I}, P<0 \cdot \mathrm{I}$ ).

Table 5. Quantities of individual elements excreted in collected caecal droppings of red grouse as a percentage of the total excreted

$\begin{array}{lcc} & \text { Mean } & \text { Range } \\ \mathrm{N} & 26 & 20-29 \\ \mathrm{P} & 63 & 46-75 \\ \mathrm{Ca} & 4 & 3-5 \\ \mathrm{Mg} & \mathrm{I} & 9-18 \\ \mathrm{~K} & 87 & 80-96 \\ \mathrm{Na} & 45 & 33-53\end{array}$

Table 6. Apparent digestibility of some constituents of heather for red grouse

Bird ...
Date of collection
Body-wt loss $(\mathrm{g} / \mathrm{d})$
DM intake $(\mathrm{g} / \mathrm{d})$
DM output $(\mathrm{g} / \mathrm{d})$
Woody droppings
Caecal droppings
ME value $(\mathrm{kcal} / \mathrm{g}$ of the
dietary DM; $/ \mathrm{g})$

DM
Lignin
Holocellulose
- Cellulose
Soluble carbohydrates
$\alpha-$ Amino nitrogen
Ether extractives
Soluble tannins

\begin{tabular}{|c|c|c|c|c|}
\hline$A_{\text {I }}$ & $\mathrm{A}_{4}$ & A 6 & $\mathrm{~S}_{2}$ & 56 \\
\hline 29. xi to $5 . \mathrm{xii}$ & $20-26 . x i$ & 28. $x$ to $2, x i$ & $27-31 . v$ & $4-8$. vi \\
\hline $\begin{array}{l}12 \\
62 \cdot 0\end{array}$ & $\begin{array}{c}2 \\
7 \pi \cdot 3\end{array}$ & $\begin{array}{c}I \\
80 \cdot I\end{array}$ & $\begin{array}{c}3 \\
72 \cdot 5\end{array}$ & $\begin{array}{c}6 \\
68 \cdot 6\end{array}$ \\
\hline $\begin{array}{c}38 \cdot I \\
5 \cdot 6 \\
\mathrm{I} \cdot 58 ; 66 \mathrm{IO}\end{array}$ & $\begin{array}{c}44 \cdot 6 \\
6 \cdot 7 \\
I \cdot 46 ; 6110\end{array}$ & $\begin{array}{c}57 \cdot 0 \\
6 \cdot 2 \\
I \cdot 10 ; 4600\end{array}$ & $\begin{array}{c}44 \cdot I \\
6 \cdot 4 \\
I \cdot 54 ; 6440\end{array}$ & $\begin{array}{c}43 \cdot 9 \\
6 \cdot 2 \\
r \cdot 36 ; 5690\end{array}$ \\
\hline \multicolumn{5}{|c|}{ Apparent digestibility } \\
\hline 30 & 28 & $2 I$ & 30 & 27 \\
\hline 20 & I2 & $I$ & 8 & ro \\
\hline I8 & II & $-I$ & 22 & 22 \\
\hline $\begin{array}{l}24 \\
83\end{array}$ & $\begin{array}{r}9 \\
83\end{array}$ & $\begin{array}{r}-9 \\
78\end{array}$ & $\begin{array}{l}\text { I9 } \\
66\end{array}$ & $\begin{array}{l}\text { II } \\
6 \text { I }\end{array}$ \\
\hline $3 I$ & $3 I$ & 24 & $4^{2}$ & $4^{8}$ \\
\hline 33 & 30 & 30 & 33 & 20 \\
\hline 37 & 35 & 46 & $3 \mathrm{I}$ & 25 \\
\hline
\end{tabular}

DN, dry matter; ME, metabolizable energy.

\section{Digestion of energy and organic constituents}

Considering both autumn and spring trials together, the digestibility of heather dry matter was $2 \mathbf{I}-30 \%$, and was correlated $(r=0.99)$ with metabolizable energy (ME) (I. IO-I.58 kcal $/ \mathrm{g}$, or $4 \cdot 60-6 \cdot 6 \mathrm{I} \mathrm{kJ} / \mathrm{g}$; Table 6$)$. In the autumn trial, the calculated intake of food by the birds varied from 62.0 to $80.1 \mathrm{~g} / \mathrm{d}$ and digestibilities of dry matter, energy, lignin, holocellulose and $\alpha$-cellulose varied inversely with intake.

In the spring trial the heather had just started to grow and differed in chemical composition from the autumn heather (Tables I, 2). It contained more holo- and $\alpha$ cellulose and $\alpha$-amino $\mathrm{N}$, similar amounts of lignin and crude fat, and less soluble carbohydrates. For all birds in both trials the proximate composition of the droppings was similar. Hence differences in the digestibilities of some constituents between the 
two trials were largely due to the initial differences in the food. Thus, the digestibility of $\alpha$-amino $\mathrm{N}$ was greater in the spring than in the autumn, associated with the fact that the food contained more $\alpha$-amino $\mathrm{N}$ in the spring. By contrast, the digestibility of soluble carbohydrate was lower in the spring, associated with a lower concentration in the food.

The situation was more complex with cellulose because, judging by the autumn trial, its digestibility varied inversely with intake. However, intake by birds $\mathrm{S}_{2}$ and $\mathrm{S} 6$ (spring) was similar to that of bird $\mathrm{A}_{4}$ (autumn), yet the former birds digested more holocellulose and $\alpha$-cellulose; again this was associated with a higher concentration in the food.

Table 7. Molar proportions of volatile fatty acids (VFA) in caecums and intestines of red grouse on a diet of heather

\begin{tabular}{|c|c|c|c|c|c|c|c|}
\hline & $\begin{array}{c}\text { Total VFA } \\
\text { (mmolil) }\end{array}$ & $\begin{array}{l}\text { Acetic } \\
\text { acid }\end{array}$ & $\begin{array}{l}\text { Propionic } \\
\text { acid }\end{array}$ & $\begin{array}{l}\text { Iso- } \\
\text { butyric } \\
\text { acid }\end{array}$ & $\begin{array}{l}\text { Butyric } \\
\text { acid }\end{array}$ & $\begin{array}{l}\text { Iso- } \\
\text { valeric } \\
\text { acid }\end{array}$ & $\begin{array}{l}\text { Valeric } \\
\text { acid }\end{array}$ \\
\hline \multicolumn{8}{|l|}{ Caecums: } \\
\hline 27. iv. 69 & $4 I$ & 6I & 12 & 3 & 22 & 2 & $\circ$ \\
\hline I7. iv. 69 & $3^{6}$ & $6 \mathrm{I}$ & I4 & 5 & I3 & 4 & $\mathbf{r}$ \\
\hline I7. iv. 69 & 35 & 59 & 14 & 5 & 16 & 3 & 2 \\
\hline $\begin{array}{l}\text { Lower small intestine } \\
\text { (combined sample) }\end{array}$ & 37 & 62 & 12 & 7 & 19 & I & $\circ$ \\
\hline $\begin{array}{l}\text { Large intestine } \\
\text { (combined sample) }\end{array}$ & 17 & 67 & 7 & 9 & 13 & 0 & o \\
\hline
\end{tabular}

Concentrations of crude fat and lignin were similar in the food in both trials. Fat retention was similar $(30-33 \%)$ in four birds but lower in bird S6, whose woody droppings contained more fat than those of the other birds for no obvious reason. The spring results for the digestibility of lignin followed the same pattern as the autumn results, being inversely related to dry-matter intake (general $r=0.97 ; P<0.01$ ). The heather eaten contained large amounts $(c .10 \%)$ of soluble tannin and the birds apparently digested $25-46 \%$ of this; that is, approximately $2 \mathrm{~g} / \mathrm{d}$.

Total concentrations of VFA (Table 7) were similar in the caecal contents and lower part of the small intestine $\left(35^{-}-\mathrm{I} \mathrm{mmol} / \mathrm{I}\right)$ in three wild grouse that were shot to provide these measurements. These values are similar to the results of McBee \& West (1969), who studied willow ptarmigan (Lagopus lagopus) eating Salix spp. It is about one-third of the concentrations normally found in the rumen and caecum of ruminants. The concentration in the large intestine was about half this value. Molar proportions (Table 7 ) in all the samples fell with reported ranges for the caecal contents of sheep (cf. Ørskov, Fraser \& Kay, I 969 ). Acetate was in the lower part of the range usual for sheep; butyrate and isobutyrate were in the higher part.

\section{$N$ metabolism}

There were major differences between the woody and caecal droppings, both in total $\mathrm{N}$ content and in the chemical form of this $\mathrm{N}$ (Table 8). Neither uric acid nor ornithuric acid was detected in the caecal droppings, indicating that the urine was excreted along with the woody droppings. The relatively large amounts of ammonia and ammonium salts in the woody droppings (about $0.4 \%$; Table 8 ) were probably 
derived largely from ammonium salts in the urine; small amounts (about $0.04 \%$ ) were found in the caecal droppings. Amide $\mathrm{N}$ formed a similar proportion (about $10 \%$ ) of the total $\mathrm{N}$ in both types of droppings. This proportion was about twice that in the heather eaten.

\section{Table 8. Some nitrogenous constituents in heather and in the droppings of} red grouse, as \% nitrogen on a dry-matter basis

\begin{tabular}{|c|c|c|c|c|c|c|c|}
\hline Bird & Total N & $\alpha$-Amino & $\mathrm{NH}_{4}^{+}$ & Amide & Urate & $\begin{array}{l}\text { Orni- } \\
\text { thurate }\end{array}$ & $\begin{array}{l}\text { Total N* } \\
\text { accounted } \\
\text { for }(\%)\end{array}$ \\
\hline \multicolumn{8}{|c|}{ Heather: crop contents } \\
\hline$A_{I}$ & r.rot & $0.5^{8}$ & 0.005 & 0.092 & 0 & 一 & 83 \\
\hline $\mathrm{A}_{4}$ & $r \cdot 03 t$ & 0.54 & 0.005 & 0.085 & $\circ$ & - & 83 \\
\hline A 6 & $1 \cdot 04 t$ & 0.57 & 0.005 & 0.090 & 0 & o & 87 \\
\hline $\mathrm{S}_{2}$ & $\mathbf{I} \cdot 20+$ & - & - & - & $\circ$ & - & - \\
\hline S6 & $\mathbf{I} \cdot \mathbf{2} 3 \dagger$ & 0.69 & 0.010 & 0.090 & $\circ$ & 一 & 87 \\
\hline \multicolumn{8}{|c|}{ Heather: picked samples } \\
\hline$A_{\text {I }}$ & 0.97 & $0.5 \mathrm{I}$ & 0.005 & 0.084 & o & $\ldots$ & 90 \\
\hline $\mathrm{A}_{4}$ & 0.94 & $0.5^{1}$ & 0.005 & 0.085 & 0 & 一 & 86 \\
\hline A 6 & $\mathrm{I} \cdot 02$ & $0-54$ & 0.007 & 0.084 & 0 & - & 83 \\
\hline $\mathrm{S}_{2}$ & $\mathbf{I} \cdot \mathbf{I} \mathbf{I}$ & 0.62 & 0.007 & 0.093 & o & -. & 87 \\
\hline S6 & I'IO & 0.63 & 0.007 & 0.089 & 0 & - & 89 \\
\hline \multicolumn{8}{|c|}{ Woody droppings } \\
\hline Ar & $2 \cdot 16$ & $0.3^{8}$ & 0.49 & 0.18 & 0.50 & 0.4 & 78 \\
\hline $\mathrm{A}_{4}$ & $\mathrm{I} \cdot 24$ & 0.40 & 0.32 & 0.13 & 0.053 & 0.2 & 85 \\
\hline A 6 & $1 \cdot 07$ & 0.40 & 0.28 & 0.11 & 0.026 & 0.3 & 90 \\
\hline $\mathrm{S}_{2}$ & 1.49 & 0.37 & 0.45 & 0.08 & 0.082 & 0.4 & 76 \\
\hline S 6 & $\mathrm{I} \cdot 59$ & $0.4 \mathrm{I}$ & $0 \cdot 48$ & 0.25 & 0.160 & 0.5 & 92 \\
\hline \multicolumn{8}{|c|}{ Caecal droppings } \\
\hline$A_{I}$ & $3 \cdot 66$ & $x \cdot 74$ & 0.049 & 0.35 & 0 & 一 & 78 \\
\hline $\mathrm{A}_{4}$ & 3.30 & $I \cdot 45$ & 0.044 & 0.32 & $\circ$ & - & 73 \\
\hline A 6 & $3 \cdot 8 \mathrm{I}$ & $x \cdot 8 \mathrm{I}$ & 0.049 & 0.34 & 0 & 0 & 77 \\
\hline $\mathrm{S}_{2}$ & 3.59 & 1.80 & 0.015 & 0.49 & 0 & - & 84 \\
\hline S6 & $3 \cdot 19$ & 0.91 & 0.025 & 0.55 & 0 & - & 58 \\
\hline
\end{tabular}

0 , not detected; - , not measured.

* Using correction factor of $\mathrm{I}^{\prime} 53$ to convert $\alpha$-amino $\mathrm{N}$ into protein $\mathrm{N}$, not including ornithurate $\mathrm{N}$. The correction factor was calculated from the known amino acid composition of heather protein ( $\alpha$-amino $\mathrm{N}=78 \%$ of total amino acid $\mathrm{N}$ ) (Moran $\&$ Pace, 1962) and the measured recovery of casein $\alpha$-amino $N$, which was used as an internal standard in the hydrolysis of heather $(84 \%)$.

$\dagger$ Not corrected for saliva.

The $\mathrm{N}$ metabolism of the birds was obviously affected by the fact that they were losing weight. In the caecal droppings, the proportions of the various $\mathrm{N}$ fractions were quite consistent. However, in the woody droppings, the concentration of urate $\mathrm{N}$ varied considerably.

The amount of urate excreted at low weight losses was small and constituted only $2 \cdot 4 \%$ of the total $\mathrm{N}$ in bird $\mathrm{A} 6$, whose weight loss was $\mathrm{r} / \mathrm{d}$. This amount increased progressively with increasing weight losses to $23 \%$ of the total $\mathrm{N}$ in bird AI, which lost $12 \mathrm{~g} / \mathrm{d}$ (Tables 5,8 ). The amount of ammonium salts in the intestinal droppings remained more nearly constant than the amount of urates, although the birds which lost weight at the rate of 3,6 and $\mathrm{i} 2 \mathrm{~g} / \mathrm{d}$ excreted more ammonium salts than those losing I and $2 \mathrm{~g} / \mathrm{d}$. Similarly the birds which lost 6 and $\mathrm{I} 2 \mathrm{~g} / \mathrm{d}$ excreted more amide $\mathrm{N}$ than those losing $\mathrm{I}, 2$ and $3 \mathrm{~g} / \mathrm{d}$. 
At low weight loss (bird A6), $\alpha$-amino $\mathrm{N}$ formed some $37 \%$ of the total $\mathrm{N}$ in the woody droppings, ammonium salts $26 \%$ and amide $\mathrm{N}$, mostly as ornithuric acid, $10 \%$.

Creatine and creatinine $\mathrm{N}$ determinations were unreliable owing to interfering substances in the extracts even after treatment with PVP. However, the results were sufficient for us to conclude that creatine and creatinine formed a very small proportion of the $\mathrm{N}$ excreted, probably not more than $\mathrm{r} \%$.

\section{DISCUSSION}

\section{Role of caecums}

The caecal droppings contained high concentrations of some elements compared with the intestinal droppings and low concentrations of cellulose and sometimes of lignin. This indicates that the metabolic activities taking place in the caecums are different from those in the small intestine. Judging by the fact that no uric or ornithuric acid was detected in the caecal droppings, urine was excreted along with the intestinal droppings and was not the source of the high concentrations of $N, P, K$ and $\mathrm{Na}$ in the caecal droppings. These may in part have been derived from bacterial remains, as may the relatively large amounts of soluble carbohydrates.

The high concentrations of soluble tannin in the caecal droppings could be explained if it was relatively inert in the caecums and became increasingly concentrated as more labile substances were digested.

The low concentrations of fat possibly occurred because the more accessible fats in the liquid fraction of the chyme had already been absorbed from the small intestine.

The fact that no cellulose was detected in the caecal droppings may have been partly due to the possible presence of particles small enough to pass through our filter (porosity 4). Suomalainen \& Arhimo (1945) found cellulase activity in the caecal contents of various tctraonids, and McBee \& West (1969) found significant but highly variable rates of fermentation and concentrations of VFA in the caecums of willow ptarmigan eating Salix spp. in Alaska. It seems likely that some, if not all, of the digestion of cellulose noted in these trials occurred in the caecums.

Neither Suomalainen \& Arhimo (I945) nor McBee \& West (I969) found any indication of fermentation in the small intestine. This is in direct contrast with the result in Table 7 , where the concentrations of VFA are similar in both the lower end of the small intestine and the caecums.

\section{Digestion of energy and proximate constituents}

Digestion of the dry matter of heather by red grouse (2I-30\%; Table 6) was low but similar to the digestion of Vaccinium myrtillus L. shoots by willow grouse (Lagopus lagopus; Pulliainen, Paloheimo \& Syrjälä, r968). Grouse weighing about $600 \mathrm{~g}$ ate $62-80 \mathrm{~g}$ of heather (dry basis) which was equivalent to a ME intake of 88-r12 kcal/d, i.e. about $75^{-95} \mathrm{kcal} / \mathrm{roO} \mathrm{g}$ metabolic body-weight ( $\mathrm{W}^{0.75}$ ). This compares with a maintenance requirement of about $75 \mathrm{kcal} / 100 \mathrm{~g}$ metabolic body-weight for the $2.5 \mathrm{~kg}$ fowl (National Research Council, 1960). Judging by this comparison, and also 
because intake bore no relation to weight losses, energy intake by the grouse appeared to be adequate.

The present trials were conducted at varying temperatures, but never far below freezing point. This probably explains why the energy intake of the birds was less than the $117 \mathrm{kcal} /$ bird per d determined by West (1968) at $-20^{\circ}$ for willow ptarmigan (Lagopus lagopus) in Alaska. This was so even though the red grouse were rather heavier than West's birds; they were also more active, because their cages were larger, they picked their own food and on many days spent time interacting with wild grouse through glass windows in the sides of the cages.

The observed variations in dry-matter intake per $\mathrm{d}$ (Table 6) were inversely correlated with dry-matter digestibility $(r=-0.80 ; P<0 . \mathrm{I})$ and lignin digestibility $(r=-0.97 ; P<0.01)$. Holocellulose digestibility was also related inversely to intake in the autumn trial.

The variations in dry-matter digestibility could to some extent be accounted for by variations in the digestion of holocellulose and lignin. The two extreme values for dry-matter digestibility were $21 \%$ (bird A6) and 30\% (AI). Bird A6 digested virtually no holocellulose or lignin, A I digested $18 \%$ and $20 \%$ respectively. Thus holocellulose and lignin digestion combined should have accounted for $0 \cdot 18 \times 37+$ $0.20 \times 2 \mathrm{I}=\mathrm{II} \%$ of the difference in dry-matter digestibility between the two birds, a value agreeing within experimental error with the $9 \%$ observed. These observations suggest that some of the variation in digestibility could be explained by decreased intake causing an increase in the length of time that the food remained in the gut, thus allowing more time for lignin and holocellulose to be digested. This would cause the observed increases in digestibility and $M E$ associated with lowered intake.

Assuming that the ME of digested holocellulose is $4 . \mathrm{I} \mathrm{kcal} / \mathrm{g}$, then $0.37 \times 0.18 \times$ $4 \cdot I=0.27 \mathrm{kcal} / \mathrm{g}$ of the difference of $0.48 \mathrm{kcal} / \mathrm{g}$ in dietary $\mathrm{ME}$ between the results obtained with birds A I and A6 would be accounted for by the digested holocellulose. Conceivably, part of the remaining $0.2 \mathrm{I} \mathrm{kcal} / \mathrm{g}$ might have been energy derived from the digested lignin $(0.042 \mathrm{~g}$ digested lignin/g dry matter in food).

These results also explain variations in earlier work on the digestion of heather by red grouse (Moss, 1967 ). One trial, carried out in autumn 1965 , gave results similar to those of the present trials, mean digestibility of dry matter being $26 \%$, of lignin $3 \%$, and of holocellulose $17 \%$, with a mean intake of $65 \mathrm{~g} / \mathrm{d}$ for three birds. Two later trials, in late winter and spring 1966 , gave much higher values for digestibility, dry-matter digestibility being $37 \%$, lignin $28 \%$, holocellulose $24 \%$ and intake $47 \mathrm{~g} / \mathrm{d}$ for nine birds. There were differences in experimental technique. In the first (1965) trial, birds were allowed to change on to the heather diet relatively slowly, as in the present trials. In the following (1966) trials, the change-over was made much more rapidly. Presumably as a result of this, the birds' intake was much lower and the digestibility of dry matter, lignin and holocellulose increased.

If these two sets of results are incorporated into a new calculation of the correlation noted above between dry-matter intake and digestibility, the relationship becomes statistically highly significant $(r=-0.94 ; P<0.0$ I).

The results summarized here are slightly different from those given by Moss ( 1967$)$ 
because they include the correction for $\mathrm{Mg}$ loss associated with weight loss, which was not done earlier. The results are not presented in more detail here because of technical faults in the earlier work which made the results less accurate than those in the present paper.

Pulliainen et al. (1968), working with willow grouse eating Vaccinium myrtillus L. shoots, and Pendergast (1969) with spruce grouse (Canachites canadenis [L.]) eating pine needles reported no digestibility of fibrous constituents. In the light of the foregoing results, it would seem that fibre digestion by tetraonids is a facultative ability utilized when intake falls below a certain level. Presumably, intake by the birds of Pulliainen et al. (1968) and Pendergast (1969) was above the critical level.

\section{$N$ metabolism}

Intake of digestible protein appeared to be adequate when compared with the maintenance diet for poultry described by Wilson, Waldroup, Jones, Duerre \& Harms (1965), which was calculated to contain $14 \mathrm{~g}$ digestible protein/1000 $\mathrm{kcal} \mathrm{ME}$, using the values for the digestibility of protein in the various constituents given by Bolton (I964). In the present trials, if one assumes that the digestibility of $\alpha$-amino $\mathrm{N}$ is the same as the digestibility of crude protein $(\mathrm{N} \times 6 \cdot 25)$, the level of digestible crude protein in heather varied from 20 to $23 \mathrm{~g} / 1000 \mathrm{kcal}$ ME in the autumn trial and from $3 \mathrm{r}$ to $4 \mathrm{I} \mathrm{g} /$ $1000 \mathrm{kcal} \mathrm{ME}$ in the spring. In addition, intake of digestible protein bore no relation to weight losses. It would seem, therefore, that lack of protein was not likely to have caused the losses of weight. Doubt is thrown on this conclusion, however, by the important role of ornithuric acid in the $\mathrm{N}$ metabolism of these birds. This compound is likely to be a detoxication product (see below), and its synthesis may increase requirements for protein above $14 \mathrm{~g} / \mathrm{I}$ (000 $\mathrm{kcal} \mathrm{ME}$.

The low urate excretion by the grouse (Table 8) compared to that of poultry on their usual diets (cf. Bolton, 1957) fits the gencral pattern of decreasing urate excretion with decreasing protein intake for poultry (Tasaki \& Okumura, 1964), because the heather in these trials contained only about $7 \%$ protein. Tetraonids, like poultry, excrete more urates on a high-protein diet (Moss, unpublished results).

The ornithuric acid in the droppings was presumably formed from benzoic acid derived largely from dietary prolignins such as quinic, shikimic and chlorogenic acids, by analogy with the fact that sheep on a diet of grass excrete hippuric acid derived from this source (Martin, I969). Tannins and other polyphenols are further possible sources of benzoic acid. Ornithuric acid is an avian equivalent of the hippuric acid excreted by mammals; this is shown by the fact that birds may excrete either ornithuric or hippuric acid when fed benzoic acid (Baldwin et al. 1960), whereas mammals excrete only hippuric acid. The importance of this metabolic pathway to grouse may be assessed by the fact that $12-24 \%$ (mean $17 \%$ ) of the total $\mathrm{N}$ excreted and $19-31 \%$ (mean $25 \%$ ) of the $\mathrm{N}$ in the woody droppings was in this form.

\section{Weight losses}

Hill, Evans \& Lumsden (1968) suggested that ruffed grouse (Bonasa umbellus [L.]) could not possibly live on a diet of aspen (Populus tremuloides Michx.) buds because 
their experimental birds lost weight on this food. This was in conflict with field observations (Gullion, 1967 ) which showed that ruffed grouse live entirely on aspen buds for much of the winter.

We have concluded that our experimental birds were improperly adapted to their diet and suggest that this was also so with the ruffed grouse of Hill et al. (1968). As we did, they used birds which had been reared on an artificial diet for this work. The great variability of their results lends weight to this suggestion. This variability may well have been due to the fact that their various experimental birds, like ours, were adapted in different degrees to the new diet.

It is a pleasure to thank Dr J. Davidson, Mr S. E. Allen and Dr R. N. B. Kay for practical advice and help, Mr D. Brown for statistical advice, and Mr R. G. White and Dr A. Watson for criticism of the manuscript.

\section{REFERENCES}

Association of Official Agricultural Chemists (1965). Official Methods of Analysis roth ed. Washington, DC: Association of Official Agricultural Chemists.

Baldwin, B. C., Robinson, D. \& Williams, R. T. (1 960). Biochem. F. 76, 595 .

Bath, I. H. (1960). F. Sci. Fd Agric. II, 560.

Bolton, W. (1957). F. Sci. Fd Agric. 8, ${ }_{32}$.

Bolton, W. (1964). Bull. Minist. Agric., Lond. no. I74.

Bremner, J. M. (1965). Methods of Soil Analysis Part 2, p. I25 [ [C. A. Black, editor]. Madison, Wis.: American Society of Agronomy Inc.

Deriaz, R. E. (1961). F. Sci. Fd Agric. 12, 152.

Faichney, G. J. (1969). Aust. J. agric. Res. 20, 491.

Gullion, G. W. (1967). Conserv. Volunt. September-October, p. 23.

Hill, D. C., Evans, E. V. \& Lumsden, H. G. (1968). F. Wildl. Mgmt 32, 854.

Hoskins, J. L. (1944). Analyst, Lond. 69, 27 I.

Jenkins, D., Watson, A. \& Miller, G. R. (1963). F. Anim. Ecol. 36, 97.

McBee, R. H. \& West, G. C. (1969). Condor 7x, 54.

Martin, A. K. (1969). Proc. Nutr. Soc. 28, 65 A.

Moran, T. \& Pace, J. (1962). 7. agric. Sci., Camb. 59, 93.

Moss, R. (I967). Aspects of grouse nutrition. PhD Thesis, University of Aberdeen.

Moss, R. (1969). F. Anim. Ecol. 38, 103.

Moss, R. (1972). F. Wildl. Mgmt 36, part I. (In the Press.)

National Research Council (I960). Publs natn. Res. Coun., Wash. no. 827.

Ørskov, E. R., Fraser, C. \& Kay, R. N. B. (1969). Br. F. Nutr. 23, 217.

Owen, J. A., Iggo, B., Scandrett, F. J. \& Stewart, C. P. (1954). Biochem. F. 58, $4_{26 .}$

Pendergast, B. A. (i 969 ). Nutrition of spruce grouse of the Swan Hills, Alberta. MS Thesis, Department of Zoology, University of Alberta.

Pulliainen, E., Paloheimo, L. \& Syrjälä, L. (ı668). Suomal, Tiedeakat. Toim. Ser. A 4, no. I26.

Ritter, G. J., Seborg, R. M. \& Mitchell, R. L. (I932). Ind. Engng Chem. analyt. Edn 4, 202.

Rook, J. A. F. \& Storry, J. E. (1 962). Nutr. Abstr. Rev. 32, 1055.

Sher, I. H. (1955). Analyt. Chem. 27, 82 I.

Suomalainen, H. \& Arhimo, E. (1945). Ornis fenn. 22, 2 I.

Tasaki, I. \& Okumura, J. ( 1964 ). F. Nutr. 83, 34.

Tinsley, J. \& Nowakowski, T. Z. (1957). Analyst, Lond. 82, i 10.

Wacker, W. E. C. \& Vallee, B. L. (1964). In Mineral Metabolism Vol. 2, part A, p. 483 [C. L. Comar and F. Bronner, editors]. New York and London: Academic Press.

West, G. C. (1968). Ecology 49, 1035.

Wilson, E. A. (19I1). The Grouse in Health and in Disease, Being the Final Report of the Committee of Enquiry on Grouse Disease p. 67. London: Elder.

Wilson, H. R., Waldroup, P. W., Jones, J. E., Duerre, D. J. \& Harms, R. H. (1965). f. Nutr. 85, 29.

Wise, L. E., Murphy, M. \& D'Addieco, A. A. (1946). Paper Trade Y. 122, 35. 